\title{
KRITIČKI OSVRT NA PROPISE O TRANSFERNIM CENAMA U SRBIJI
}

\author{
Milan Negovanović \\ Privredni savetnik DOO, Bul. Kralja Aleksandra 86, Beograd, Srbija
}

\begin{abstract}
Apstrakt:
Ovaj rad predstavlja kritički osvrt na najznačajnija nepovoljna normativna rešenja u oblasti transfernih cena u Republici Srbiji i daje preporuke kako da se ona prevaziđu izmenama u samim propisima. U radu su prikazani i pozitivni efekti reforme poreskih propisa o transfernim cenama iz 2013. godine, sa posebnim naglaskom na dejstvo nove regulative na javne prihode po osnovu poreza na dobit.
\end{abstract}

\section{Ključne reči:}

transferne cene,

povezana lica,

načelo „van dohvata ruke“,

porez na dobit,

poreski bilans.

\section{UVOD}

Pre nego što se upustimo u kritičko sagledavanje propisa o transfernim cenama u Srbiji, potrebno je prvo ukazati na značaj transfernih cena za oporezivanje, zatim na definiciju povezanih lica u našoj zemlji, kao i na obaveze poslovnih subjekata u vezi sa poslovanjem sa povezanim licima.

Transfernim cenama nazivaju se cene u komercijalnim i finansijskim odnosima između povezanih lica, a najčešće se vezuju za multinacionalne kompanije sa filijalama i poslovnim jedinicama u više zemalja (u različitim poreskim jurisdikcijama), koje u međusobnim unutargrupnim poslovnim odnosima mogu ugovarati cene koje odstupaju od cena koje bi se uspostavile na tržišnom nivou sa trećim licima nezavisnim ekonomskim subjektima. U Srbiji se transferne cene moraju verifikovati za prekogranične i unutargranične transakcije između povezanih lica. Motivi za odstupanje transfernih od tržišnih cena mogu biti poreski i neporeski; za poreske administracije značajni su fiskalni evazioni razlozi koji se ogledaju u transferu dobiti iz kompanije koja posluje u zemlji sa većim poreskim opterećenjem, u povezanu kompaniju koja je registrovana u drugoj državi (poreskoj jurisdikciji), a u kojoj su poreske stope niže. Da bi se ovakva nastojanja suzbila, države su uvele posebna poreska pravila o transfernim cenama, čija se suština može opisati u zahtevu da se transakcije između povezanih lica podvrgnu utvrđivanju njihove tržišnosti, tj. da se utvrdi cena, odnosno vrednost u skladu sa načelom „van dohvata ruke" kao da se radi o poslovnim i finansijskim odnosima između nepovezanih lica. Ukoliko između rashoda i prihoda iz odnosa sa povezanim licima po transfernim cenama i cenama utvrđenim u skladu sa principom „van dohvata ruke“ postoji razlika na štetu budžeta, za tu razliku se u poreskom bilansu, uvećava oporeziva dobit.

\section{OBAVEZE POSLOVNIH SUBJEKATA U VEZI SA POVEZANIM LICIMA I TRANSFERNIM CENAMA - TRENUTNO STANJE}

U našoj zemlji transferne cene u poreskom sistemu postoje od 1991. godine, kada su prvi put uvedene tada važećim Zakonom o porezu na dobit korporacija, mada se prvi tragovi mogu pronaći u Ugovoru o izbegavanju međunarodnog dvostrukog oporezivanja koje je SFRJ zaključila sa Francuskom 1974. godine. Međutim, u periodu od 1991. do 2012. godine, prilikom obračuna poreza na dobit od strane obveznika, kao i prilikom kontrole od strane Poreske uprave, transfernim cenama se nije posvećivala značajnija pažnja. Analizom transfernih cena i usklađivanjem oporezive dobiti po tom osnovu do kraja 2012. godine pravna lica su se bavila sporadično. Od slučaja do slučaja, to su uglavnom radile veće firme koje su deo međunarodnih poslovnih sistema, kao i obveznici revizije po nalogu revizora. Značajniju pažnju transfernim cenama nije posvećila ni Poreska uprava, u svojim kancelarijskim i terenskim kontrolama u ranijem periodu. Zbog svega navedenog, najveći broj privrednih subjekata prelazio je preko analize transfernih cena i u poreskom bilansu u rubrikama u kojima se prikazivao iznos rashoda i prihoda po transfernim $i$ tržišnim cenama, iskazivao je isti iznos, te nije vršeno usklađivanje poreske osnovice. Izuzetak je predstavljala umanjena kapitalizacija i obračun kamata „van dohvata ruke“.

Međutim, izmenama i dopunama Zakona o porezu na dobit pravnih lica (ZPDPL) koje su usvojene u decembru 2012. godine, a čija je primena počela 2013. godine, izvršene su korenite izmene u oblasti transfernih cena i one postaju predmet značajnijeg interesovanja privrednih subjekata i poreskih vlasti. Ovim izmenama uveden je veliki broj novina, od kojih kao veoma važnu izdvajamo obavezu svih pravnih lica (sem nedobitnih organizacija), preduzetnika (sem paušalaca), 
kao i ogranaka i drugih poslovnih jedinica stranih pravnih lica koje posluju na teritoriji Republike Srbije da počev od 2013. godine uz poreski bilans, nadležnom poreskom organu, obavezno predaju i dokumentaciju o transfernim cenama. Dokumentacija o transfernim cenama predaje se u vidu izveštaja o transfernim cenama čiji su obavezni elementi propisani Pravilnikom o transfernim cenama i metodama koje se po principu „van dohvata ruke“ primenjuju kod utvrđivanja cene transakcija među povezanim licima (u daljem tekstu: Pravilnik o transfernim cenama). Izveštaj o transfernim cenama predaje se u kompletnom ili skraćenom obliku, o čemu ćemo više pisati u nastavku teksta. Osim toga, zakonskom izmenom izvršena je redefinicija pojma povezanog lica za poreske svrhe, što je rezultovalo povećanjem broja lica povezanih sa obveznikom (prag kapital-učešća i glasačkih prava spušten je sa $50 \%$ na $25 \%$, povezana lica sa pravnim licem su i fizička lica koja su u rodbinskim i (van)bračnim vezama sa vlasnikom koji ima 25\% i više kapitala i glasačkih prava, sva pravna lica koja su registrovana u zemljama "poreskih rajeva" su povezana sa domaćim obveznikom sa kojim posluju), a povećan je i broj metoda koje se za proveru transfernih cena mogu koristiti.

Povezana lica za svrhe analize transfernih cena određena su čl. 59. ZPDPL prema kome se od 2013. godine licem povezanim sa obveznikom smatra(ju):

1. lice (fizičko ili pravno, domaće ili strano) koje direktno ili indirektno ima najmanje $25 \%$ udela ili akcija u kapitalu obveznika ili u čijem kapitalu obveznik, direktno ili indirektno, učestvuje sa najmanje 25\% udela ili akcija;

2. lice (fizičko ili pravno, domaće ili strano) koje, direktno ili indirektno, ima najmanje $25 \%$ glasova u organima upravljanja ili u čijim organima upravljanja obveznik, direktno ili indirektno, ima najmanje 25\% glasova;

3. pravno lice koje nije direktno povezano sa obveznikom putem kapitala ili glasačkih prava (u prethodno navedenom smislu), ali u čijem kapitalu kao i kod obveznika isto lice, direktno ili indirektno, poseduje najmanje $25 \%$ udela ili akcija, odnosno glasova u organima upravljanja. Radi se o sestrinskim firmama koje imaju istog osnivača ili vlasnika koji poseduje $25 \%$ i više osnovnog kapitala/glasačkih prava;

4. fizička lica koja su u krvnom srodstvu ili rodbinski povezana sa vlasnikom (ili drugim licem) koji ima $25 \%$ i više osnovnog kapitala/glasačkih prava. Konkretno - bračni ili vanbračni drug, potomci, usvojenici i potomci usvojenika, roditelji, usvojioci, braća i sestre i njihovi potomci, dede i babe i njihovi potomci, kao i braća i sestre i roditelji bračnog ili vanbračnog druga su kao fizička lica povezana sa pravnim licem i ukoliko postoje određeni poslovni odnosi između pravnog lica i ovih fizičkih lica radi se o transfernim cenama;

5. svako nerezidentno pravno lice koje je registrovano u zemlji „poreskog raja”, tj. nalazi se na spisku jurisdikcija sa preferencijalnim poreskim sistemom koji je utvrdilo Ministarstvo finansija. Prema Pravilniku o Listi jurisdikcija sa preferencijanim poreskim sistemom, na tom spisku nalazi se 51 poreska juridikcija koja se smatraja „poreskim rajem”.
Skraćeni izveštaj o transfernim cenama se prema odredbama Pravilnika o transfernim cenama može podneti za ekonomski manje značajne transakcije koje je pravno lice, odnosno preduzetnik imao sa povezanim licima. Skraćeni izveštaj obveznik može da podnese za transakcije sa povezanim licima, osim za zajmove i kredite, koje ispunjavaju jedan od sledeća dva uslova:

1) da je transakcija sa povezanim licem jednokratna $u$ godini za koju se podnosi poreski bilans i da njena vrednost nije veća od 8.000.000 din. ili

2) ukupna vrednost transakcija sa jednim povezanim licem u toku godine za koju se podnosi poreski bilans nije veća od 8.000.000 din.

U skraćenom izveštaju poreski organ se opisno obaveštava o tipu i vrednosti transakcija sa povezanim licem i njihova vrednost se informativno prikazuje u poreskom bilansu, a obveznik ne mora da utvrđuje tržišnu vrednost tih transakcija, tj. da dokazuje da su u skladu sa načelom „van dohvata ruke" i nema obavezu da koriguje oporezivu dobit.

Kompletan izveštaj o transfernim cenama se podnosi za transakcije čija je ukupna vrednost u poreskom periodu veća od 8.000.000 din. u odnosu sa pojedinačnim povezanim licem, kao i za sve zajmove i kredite. Kompletan izveštaj predstavlja detaljnu i obimnu studiju/elaborat koja mora da sadrži podatke o analizi grupe, analizi delatnosti, funkcionalnoj analizi, metodi koja je izabrana za proveru usklađenosti transfernih cena, matematički deo u kojem se vrši obračun rashoda i prihoda po cenama „van dohvata ruke" i utvrđuje korekcija oporezive dobiti (ili se navodi zaključak da korekcije nema jer se posluje po tržišnim uslovima), kao i deo u kojem se prilažu podaci i informacije koji su korišćeni u prethodnim analizama. Ukoliko obveznik dokumentuje da između transfernih i tržišnih cena nema značajnije razlike, neće izvršiti uvećanje oporezive dobiti; u suprotnom vrši povećanje oporezive dobiti i za iznos pozitivne razlike između rashoda po transfernim cenama i rashoda po cenama „van dohvata ruke“ ili za iznos pozitivne razlike između prihoda po cenama „van dohvata ruke“ $i$ prihoda po transfernim cenama. Dakle, kompletan izveštaj potencijalno nosi u sebi korekciju poreske osnovice.

Metode za proveru usklađenosti transfernih cena u Srbiji su u skladu sa praksom zemalja OECD. Od 2013. god. povećan je broj metoda koje mogu da se koriste. Dozvoljena je primena pet metoda:

1) metoda uporedive cene na tržištu,

2) metoda cene koštanja uvećane za uobičajenu zaradu,

3) metoda preprodajne cene,

4) metoda transakcione neto marže i

5) metoda podele dobiti.

Prve tri metode spadaju u standardne (klasične) transakcione metode, koje su bile dozvoljene i pre 2013. godine. Međutim, metoda transakcione neto marže i metoda podele dobiti (spadaju u metode zasnovane na dobitku) našoj zemlji su u primeni od 2013. god. Pored navedenih pet metoda, obveznik može da koristi i bilo koju drugu metodu, ukoliko bolje odgovara okolnostima slučaja ili daje pouzdaniju procenu rezultata u skladu sa principom „van dohvata ruke“. Bitna novina je ta da metoda uporedive cene na tržištu (koja traži vrlo stroge uslove u pogledu uporedivosti koje je teško, 
ponekad gotovo nemoguće zadovoljiti, a koju je Poreska uprava zbog svoje metodološke jednostavnosti i proverljivosti sklona da favorizuje) više nema formalnu prednost nad ostalim metodama. Sada su sve metode jednake i obveznik samostalno bira onu koja najviše odgovara konketnim okolnostima slučaja.

Određeni rashodi koji su nastali iz odnosa sa povezanim licima u celokupnom iznosu se ne priznaju kao poreski rashod; to je u Srbiji slučaj sa zateznim kamatama od povezanih lica i poklonima čiji je primalac povezano lice. Posebno, potencijalno rizično područje su rashodi po osnovu primljenih usluga istraživanja tržišta, konsultantskih, marketinških i pravnih usluga, IT, inženjerskih i projektantskih usluga, kao i management fee fakturisani od povezanog lica iz inostranstva (ne isključujući ni od domaćeg pružaoca usluga) za koje treba dokazati da su uopšte pružene, zatim da služe za obavljanje delatnosti i da su obračunate po tržišnim iznosima. Ukoliko se prethodno adekvatno ne dokumentuje, poreski inspektor može zahtevati da se tretiraju kao nedokumentovan trošak ili rashod koji nije nastao u funkciji obavljanja delatnosti i izvršiti njihovo uključivanje u poresku osnovicu.

Umanjena kapitalizacija i obračun kamata „van dohvata ruke“ predstavlja poseban obračun koji se vrši za date ili primljene zajmove, odnosno kredite između povezanih lica. Što se tiče primljenih zajmova i kredita od povezanog lica po osnovu kojih su iskazani rashodi kamata shodno čl. 62 ZPDPL pravnom licu će biti priznati rashodi kamata i drugi srodni rashodi (troškovi osiguranja ili obrade zajma/kredita) do četvorostruke vrednosti prosečnog kapitala. Bankama i davaocima finansijskog lizinga rashodi kamata i srodni troškovi priznaju se do desetostruke vrednosti kapitala. Ukoliko iznos iskazanih rashoda kamata po osnovu pozajmljivanja od povezanog lica prelazi limit do četvorostuke (desetostruke) vrednosti kapitala, a što se utvrđuje na posebnom obrascu OK, razlika predstavlja poreski nepriznat iznos za koji se uvećava oporeziva dobit. Ovo usklađivanje naziva se korekcijom po osnovu utanjene kapitalizacije. Pored nje, potrebno je utvrditi iznos rashoda kamata po osnovu primljenih zajmova/kredita od povezanih lica po kamatnim stopama „van dohvata ruke“ i ukoliko su rashodi kamata obračunati po ugovorenim (transfernim) kamatnim stopama veći od rashoda kamata obračunatih po kamatnim stopama „van dohvata ruke“, za razliku se uvećava oporeziva dobit. To predstavlja drugu korekciju primenom pravila o transfernim cenama.

Ukoliko je poreski obveznik dao povezanom licu zajam ili kredit, potrebno je da utvrdi prihode od kamata po kamatnim stopama „van dohvata ruke“ i ukoliko su kamatni prihodi obračunati po ugovorenim kamatnim stopama manji od onih koji bi bili obračunati po kamatnim stopama „van dohvata ruke“, za razliku se uvećava oporeziva dobit. Između povezanih lica često su zastupljene beskamatne pozajmice (koje su dozvoljene po Zakonu o obligacionim odnosima) po osnovu kojih zajmodavac ne iskazuje prihod, a zajmoprimac ne iskazuje rashod. Kod međukompanijskih pozajmica između povezanih lica korekcija će biti izvršena kod zajmodavca i to za iznos prihoda koje bi ostvario da je zajam odobren nepovezanom licu, a koji se obračunava primenom kamatnih stopa „van dohvata ruke“.

Za potrebe obračuna rashoda, odnosno prihoda „van dohvata ruke“ mogu se koristiti kamatne stope koje objavljuje ministar finansija (državne kamatne stope) ili kamatne stope koje obveznik utvrđuje primenom opštih pravila o transfer- nim cenama. Do kraja 2012. godine obavezno su morale da se koriste državne kamatne stope, a od 2013. godine dozvoljena je upotreba drugih kamatnih stopa koje analizom uporedivosti utvrđuje sam obveznik, uz obavezu da u tom slučaju ovaj pristup koristi za sve zajmove i kredite sa svim povezanim licima.

\section{POZITIVNI EFEKTI IZMENE PROPISA O TRANSFERNIM CENAMA OD 2013. GODINE}

Pooštravanje pravila u vezi sa transakcijama sa povezanim licima i transfernim cenama donelo je niz pozitivnih efekata:

- povećani su disciplina i odgovornost prilikom ugovaranja i realizacije ekonomskih odnosa sa povezanim licima;

- prilikom izmene propisa o transfernim cenama kao izvor prava korišćene su Smernice OECD za transferne cene za multinacionalna preduzeća i poreske uprave, čime je naše zakonodavstvo usaglašeno sa najboljom svetskom praksom;

- uvedeno je oštrije oporezivanje transakcija sa povezanim licima iz zemalja poreskih rajeva u vidu stope poreza po odbitku od $25 \%$ prilikom isplate autorskih naknada, kamata, naknada po osnovu zakupa pokretne i nepokretne imovine i usluga koje fakturišu kompanije iz jurisdikcija sa privilegovanim poreskim sistemom;

- povećan je broj metoda za proveru usklađenosti transfernih cena - moguća je i primena metoda zasnovanih na dobitku;

- ukinuta je formalna prednost metode uporedive cene na tržištu (koja je ranije stvarala probleme poreskim obveznicima) i zamenjena ravnopravnošću svih metoda;

- dozvoljena je mogućnost prebijanja pozitivnih i negativnih korekcija iz poslovnih odnosa sa pojedinačnim povezanim licem i izvršen niz drugih tehničkih poboljšanja;

- ozakonjeno je smanjenje poreske osnovice iz odnosa sa povezanim licima na bazi međunarodnih poreskih ugovora;

- za potrebe obračuna kamata „van dohvata ruke ukinuto je obavezno korišćenje kamatnih stopa ministra finansija“ i poreskom obvezniku dato diskreciono pravo da tržišne kamatne stope utvrđuje primenom opštih pravila o transfernim cenama;

- preduzeti su prvi ozbiljniji koraci u edukaciji Poreske uprave iz oblasti transfernih cena i razmišlja se da se u ovoj instituciji formira posebno odeljenje specijalizovano za kontrole transfernih cena.

\section{FISKALNI EFEKAT POOŠTRAVANJA PROPISA O TRANSFERNIM CENAMA}

Izmenama i dopunama ZPDPL koje se primenjuju od 2013. godine stopa poreza na dobit pravnih lica povećana je sa $10 \%$ na $15 \%$ (za preduzetnike je ostala $10 \%$ ), ukinut je „sektorski“ poreski kredit za investicije u osnovna sredstva za proizvodne delatnosti (koji je iznosio 80\% izvršenih ulaganja do $100 \%$ obračunatog poreza), kao i drugi poreski podsticaji (oslobođenje za ulaganja u nedovoljno razvijenim područji- 
ma, poresko oslobođenje poreza na dobit po osnovu ulaganja u koncesiono preduzeće) i, naposletku, značajno su pooštrena pravila o transfernim cenama. Počev od 2014. god. ukinut je i standardni poreski kredit za ulaganja u osnovna sredstva (koji je za mala pravna lica iznosio 40\% izvršenih ulaganja, do $70 \%$ obračunatog poreza; a za srednja i velika pravna lica $20 \%$ izvršenih ulaganja do 33\% obračunatog poreza).

Pozitivni budžetski efekti navedenih poreskih izmena osetili su se u 2013. i 2014. god. kada su prihodi od poreza na dobit povećani u odnosu na prethodne godine. Konkretno, ukoliko za polaznu uzmemo 2012. godinu kada su prihodi od poreza na dobit na konsolidovanom nivou iznosili 54,8 milijardi din. u naredne dve godine ostvaren je rast. U 2013. god. iznosili su 60,7 mlrd. din, a u 2014. god. ostvareni su prihodi od poreza na dobit od 72,7 mlrd. din., što je povećanje od 10,8\%, odnosno $19,8 \%$ u odnosu na prethodnu godinu. U odnosu na budžetirani iznos od 65,8 mlrd. din. u 2014. god. prihodi od poreza na dobit (72,7 mlrd. din.) ostvarili su prebačaj od 6,9\% (Ministarstvo finansija Republike Srbije, 2015).

Međutim, u 2015. godini dolazi do pada realizacije poreza na dobit. U vreme pripreme ovog rada u poslednjem objavljenom mesečnom izveštaju Fiskalnog saveta za avgust 2015. god. navedeno je da su prihodi od poreza na dobit za 2015. god. budžetirani na iznos od 76 mldr. din. a tekuća prognoza je da će iznositi 64 mlrd. dinara. Drugim rečima, očekuje se da će prihodi od poreza na dobit podbaciti za oko $12 \mathrm{mlrd}$. din. (Fiskalni savet Republike Srbije, 2015).

Slični zaključci mogu se izvući i iz Biltena javnih finansija za jul 2015. godine koji je objavljen na sajtu Ministarstva finansija. U Biltenu se navodi podatak da su u periodu od januara do avgusta 2014. godine od poreza na dobit ostvareni konsolidovani prihodi države u iznosu od 55,0 mlrd. din., a da u periodu od januara do avgusta 2015. godine isti iznose 46,7 mlrd. dinara, što je nominalni pad od $15,1 \%$, a realni pad od 16,3\% (Ministarstvo finansija Republike Srbije, 2015).

Naravno, nemoguće je egzaktno kvantitikovati efekat izmene poreskih propisa i rigidnijih pravila o transfernim cenama na povećanje/smanjenje realizacije poreza na dobit jer se radi o multifaktorskom fenomenu iz kojeg nije izvodljivo izolovati samo jednu promenljivu. Međutim, ukoliko se u 2016. i narednim godinama nastavi tendencija smanjivanja realizacije poreza na dobit, biće potrebno preispitati celishodnost smanjenja efektivne stope poreza na dobit (kroz smanjenje nominalne stope i vraćanje dela poreskih podsticaja), kao i kroz relaksiranje zahteva u vezi sa transfernim cenama koji predstavljaju veliko administrativno opterećenje i trošak za preduzetnike, mikro i mala pravna lica koji premašuje korist koja se ubira kroz veće poreske prihode, a jedini dobitnici su eksterni revizori i konsultanti koji uz visoku naknadu izrađuju elaborate o transfernim cenama.

\section{NEDOSTACI PROPISA O TRANSFERNIM CENAMA I PREPORUKE ZA NJIHOVO OTKLANJANJE}

Definicija povezanog lica. U čl. 59. st. 4. ZPDPL koristi se formulacija „najmanje 25\% glasova u organima upravljanja "što upućuje na to da povezano lice može biti ono (fizičko ili pravno) koje ima ili u kojem obveznik ima najmanje $25 \%$ i više glasova u upravnom odboru, odboru direktora, nadzornom odboru i sl., a ne samo u skupštini. Nezvanično, organima upravljanja u ovom kontekstu smatra se samo skupština/vlasnik, mada čitajući ZPDPL onako kako je napisan i tumačeći ga dura lex sed lex, tako ne proizilazi (po Zakonu o privrednim društvima organ upravljanja nije samo skupština, već su to i direktor, odbor direktora i slično).

Ministarstvo finansija izdalo je nekoliko mišljenja po kojima dva ili više pravnih lica čiji su osnivači ili vlasnici lica koja su u rodbinskim vezama (otac - sin, suprug - supruga, brat - sestra i sl.) nisu povezana pravna lica, dok bi dve preduzetničke radnje, ili privredno društvo ili preduzetnička radnja čiji su osnivači lica u rodbinskim vezama bila povezana lica, što je nelogično i neprincipijelno, jer tada povezanost zavisi od oblika organizovanja privrednog subjekta.

Takođe, Ministarstvo finansija je objavilo mišljenje po kojem direktor nije povezano lice sa pravnim licem u kojem je direktor (osim ukoliko ima $25 \%$ i više glasačkih prava, što najčešće ne postoji) iz čega proizilazi da pravno lice A u kojem je neko fizičko lice direktor i pravno lice B u kojem je isto fizičko lice vlasnik najmanje $25 \%$ kapitala nisu povezana lica i ne podležu transfernim cenama, što stvara prostor za zloupotrebe. Direktor je osoba koja ima više direktnog uticaja na operativno poslovanje i sklapanje tekućih poslova od akcionara ili člana društva koji ima 25\% kapitala i samim tim je u daleko većoj mogućnosti da izvrši upliv na cene po kojima će se odvijati poslovanje, te je ovakvo tumačenje po državu kontraproduktivno. Ovo je posebno prisutno kod društava čiji je kapital usitnjen tj. gde postoji disperzija učešća na veliki broj vlasnika gde nijedan nema kritično kontrolno učešće.

Izveštaj o transfernim cenama u skraćenom obliku. Treba proširiti broj slučajeva za koje je moguće podneti izveštaj o transfernim cenama u skraćenom obliku i na sledeće transakcije sa povezanim licima: pravno lice/preduzetnik dobilo je beskamatni zajam od povezanog lica po osnovu kojeg nisu iskazani rashodi po osnovu kamata, evidentirani rashodi od povezanog lica koji su u poreskom bilansu iskazani kao nepriznat rashod u celokupnom iznosu, dodatne novčane uplate od strane vlasnika pravnog lica koje su regisrtovane kao povećanje kapitala, dodatne uplate člana društva kojima se ne povećava kapital, isplata dividende, odnosno udela u dobiti pravnog lica.

Nerealizovani avansi iz odnosa sa povezanim licima. Takođe, trebalo bi bolje urediti način dokumentovanja datih ili primljenih avansa između povezanih lica koji nisu realizovani do kraja perioda i po osnovu kojih nisu iskazani rashodi i prihodi. Trenutno ne postoji saglasnost oko toga u kojem poreskom periodu i u kojoj meri avanse treba prikazati u izveštaju o transfernim cenama:

a) da li u godini kada je avans dat ili primljen treba utvrdivati cene „van dohvata ruke“ i u toj godini ih uključivati u izveštaj o transfernim cenama ili

b) to treba uraditi u godini kada se izvrši promet dobara i usluga i iskažu rashodi/prihodi ili

c) to treba raditi u obe godine?

Po autorovom mišljenju, kod avansa utvrđivanje cene $\mathrm{u}$ skladu sa principom „van dohvata ruke“ zavisi od izabrane metode; ako je to metoda uporedive cene na tržištu uporedive tržišne cene treba utvrditi u godini kada je avans dat ili primljen (uz odgovarajuće korekcije za razlike u narednom periodu), a dokumentovanje u izveštaju o transfernim cenama treba da se izvrši u godini kada su iskazani rashodi, odnosno prihodi u finansijskim izveštajima. 
(Ne)upotrebljivost kamatnih stopa „van dohvata ruke“ ministra finansija. Najveći broj obveznika prilikom obračuna rashoda/prihoda od kamata na zajmove/kredite između povezanih lica koristi kamatne stope koje utvrđuje ministar finansija. Problem sa ovim godišnjim kamatnim stopama je što se primenjuju samo na poresku godinu na koju se odnose, a objavljuju se tek u prvom kvartalu naredne godine. One se mogu koristiti za potrebne redovne godišnje poreske prijave poreza na dobit. Međutim, ne mogu se koristiti prilikom sastavljanja vanredne (periodične) poreske prijave koja se podnosi u toku godine zbog izmene akontacija, prestanka obavljanja delatnosti usled likvidacije, stečaja ili statusne promene. Na primer, pravno lice želi da podnese vanrednu poresku prijavu i poreski bilans u julu 2015. god. zbog izmene akontacija poreza na dobit, a od početka godine do kraja jula 2015. imalo je date ili primljene zajmove sa povezanim licima. Ovo pravno lice ne može da koristi kamatne stope MFIN, jer će za 2015. god. biti objavljene tek u prvom kvartalu 2016. god. a poslednje objavljene kamatne stope za 2014. god. takođe su neupotrebljive, jer se one mogu koristiti samo za 2014. god. Ne postoji pravni osnov da se za potrebe periodične prijave, do objavljivanja novih kamatnih stopa, koriste poslednje objavljene kamatne stope MFIN. Takva mogućnost je postojala do kraja 2012. god. kada je u Pravilniku o sadržaju poreskog bilansa i drugim pitanjima od značaja za način utvrđivanja poreza na dobit pravnih lica postojala norma da se do objavljivanja novih podataka, mogu koristiti poslednji objavljeni podaci. Međutim, u postojećem Pravilniku u poreskom bilansu i u drugim propisima iz oblasti transfernih cena, takva norma ne postoji.

Identičan problem postoji prilikom plaćanja kamata po osnovu zajma/kredita nerezidentnim povezanim licima kada se obveznik poziva na međunarodni ugovor o izbegavanju dvostrukog oporezivanja (MUIDO) koji daje mogućnost da se porez po odbitku na kamatu, umesto po zakonskoj stopi poreza od $20 \%$ na bruto osnovicu, plati po beneficiranoj stopi iz ugovora koja u većini ugovora iznosi 10\%, a u ugovorima sa Nemačkom, Norveškom, Finskom, Francuskom, Holandijom i Švedskom iznosi 0\%. Međutim, prema MUIDO, domaće pravno lice beneficiranu stopu od $10 \%$ ili $0 \%$, prilikom isplate kamate nerezidentnom povezanom licu, može da primeni samo do iznosa tržišnog iznosa kamate utvrđenog po kamatnoj stopi „van dohvata ruke“, a na razliku preko tržišnog iznosa mora da plati porez po stopi od $20 \%$. Prilikom primene MUIDO, za ove svrhe, takođe ne mogu da se koriste kamatne stope MFIN jer u momentu isplate za tekuću godinu nisu objavljene, a za kamatne stope za prethodnu godinu ne mogu da se koriste. Ovu pravnu barijeru treba otkloniti izmenom Pravilnika o kamatnim stopama tako što će se predvideti da se do objavljivanja novih podataka za tekuću godinu, mogu koristiti poslednji objavljeni podaci.

Poreski propisi ne predviđaju mogućnost zaključenja prethodnih sporazuma sa Poreskom upravom o transfernim cenama. $U$ većini drugih zemalja poreskim propisima normativno je uređena mogućnost zaključenja prethodnih sporazuma o transfernim cenama između poreskog obveznika i poreske uprave. Takvi sporazumi predviđeni su i Smernicama OECD za transferne cene. Dosadašnja iskustva zemalja koje su primenjivale sporazume su pozitivna i zemljama se preporučuje da ih omoguće. Radi se o pisanom ugovoru kojim se na zakonom uređen i transparentan način između poreskog obveznika i poreske uprave potvrđuje saglasnost oko izabrane metode i metodologije koju će obveznik koristiti, pretpostavki koje će se upotrebljavati, parametara koji će biti u upotrebi itd. Na taj način, poreskom obvezniku se olakšava sprovođenje pravila o transfernim cenama, pravna nesigurnost se svodi na najmanju moguću meru, a Poreskoj upravi se olakšava kontrola, koja se svodi na proveru da li se obveznik pridržavao odredaba ugovora. Zakon o porezu na dobit pravnih lica, Zakon o poreskom postupku i poreskoj administraciji i ostali propisi ne predviđaju mogućnost zaključenja ovakvih ugovora, što bi u najskorijoj budućnosti trebalo izmeniti jer je to u interesu u privrede i budžeta.

Stručna osposobljenost i softverska opremljenost Poreske uprave za kontrolu transfernih cena. Međunarodna finansijska korporacija je u oktobru 2013. godine održala dvodnevni kurs "Uvod u transferne cene za inspektore CVPO", predavači su bili stručnjaci Svetske banke. U junu i julu 2015. godine oko 300 inspektora Poreske uprave iz četiri regionalna centra (Beograd, Novi Sad, Kragujevac i Niš) prošlo je kroz obuku o osnovnim pravilima i načelima transfernih cena, koju su održali Privredni savetnik i Pravni fakultet Univerziteta u Beogradu. Moguć je nastavak ove obuke u vidu višeg nivoa praktičnog osposobljavanja za manju grupu od 20 - 30 inspektora kroz radionice, studije slučajeva i simulacije poreskih kontrola na „živim“ primerima. Bila bi velika šteta ako se, zbog nedostatka finansijskih sredstava, edukacija Poreske uprave ne bi nastavila i ako se ne bi izvršila reorganizacija u pravcu formiranja posebnog odeljenja. Transferne cene predstavljaju najsloženiju i najdelikatniju materiju u poreskom pravu, koja je lišena egzaktnosti svojstvene ostalim poreskim instrumentima, pa je uža specijalizacija i podizanje profesionalnih kapaciteta Poreske uprave, najvažnija aktivnost za pravilnu i uspešnu primenu ovih propisa. U rukama nedovoljno stručne osobe transferne cene mogu dovesti do milionskih sudskih sporova sa poreskim obveznicima i velikih šteta ne samo po privredne subjekte, već i po poresku administraciju.

Trenutno, Poreska uprava nije softverski opremljena za kontrole transfernih cena, jer nema nijednu bazu podataka koja sadrži potrebne podatke za transferne cene. Poreska kontrola je nezamisliva bez korišćenja komercijalnih baza podataka kao što su: Amadeus, Orbis, Thomson\&Reuters, Rejting, Skoring itd. Privredni subjekti u najvećem broju slučajeva koriste navedene baze (osim kada primenjuju metodu uporedive cene na tržištu ili kada raspolažu internim podacima i maržama). Zato bi u narednom periodu prioritet Poreske uprave trebalo da bude obezbeđivanje odgovarajuće komercijalne baze podataka, bez koje Poreska uprava ne može da parira poreskom obvezniku.

\section{ZAKLJUČAK}

Izmene Zakona o porezu na dobit pravnih lica i pratećih podzakonskih propisa u oblasti transfernih cena donele su niz pozitivnih promena u pravcu prihvatanja Smernica OECD za transferne cene kao ishodišta domaćeg prava, povećanja broja zakonski prihvatljivih metoda, uz ukidanje formalne prednosti metode uporedive cene na tržištu u odnosu na ostale metode. Međutim, zabrinjava pad javnih prihoda od poreza na dobit u 2015. godine, koji ukoliko se nastavi ukazuje na to da povećanje efektivne poreske stope i pooštravanje zahteva u vezi sa transfernim cenama nije dalo očekivane rezultate. $\mathrm{U}$ domenu transferih cena, aktuelni propisi 
u značajnoj meri predstavljaju prilično administrativno opterećenje za preduzetnike, mikro i mala pravna lica i dovode do velikih troškova zbog angažovanja spoljnjeg konsultanta ili revizora za izradu studije. Potrebno je otklanjanje niza nedostataka koji su u praksi uočeni od 2013. god., a koji su $\mathrm{u}$ radu sagledani. Osim izmena poreskih propisa, akcenat u daljim reformskim procesima treba staviti na nastavak obuke inspektora Poreske uprave iz oblasti transfernih cena, formiranje posebnog odeljenja čiji će se inspektori specijalizovati za kontrole transfernih cena, nabavku softvera i baza podataka koje sadrže podatke potrebne za te kontrole, kao i na institucionalizovanje prethodnih sporazuma o transfernim cenama zaključenih između poreskog obveznika i Poreske uprave.

\section{LITERATURA}

Feinschreiber, R., \& Kent, M. (2012). Transfer pricing handbook: Guidance on the OECD regulations. Hoboken, NJ: John Wiley \& Sons.

Fiskalni savet Republike Srbije. (2015). Fiskalna konsolidacija u 2015. god. i osnovni reformski izazovi. Preuzeto 20. oktobra 2015. sa http://www.fiskalnisavet.rs/doc/ocene-i-misljenja/2015/fiskalna_konsolidacija_u_2015._i_reformski_izazovi.pdf

Fiskalni savet Republike Srbije. (2015). Mesečni izveštaj Fiskalnog saveta RS o fiskalnim kretanjima u avgustu 2015. god. Preuzeto 20. oktobra 2015. sa http://www.fiskalnisavet.rs/ latinica/mesecni-izvestaji.php
Ministarstvo finansija Republike Srbije. (2015). Bilten javnih finansija za mesec jul 2015. god. Preuzeto 20. oktobra 2015. sa http://www.mfin.gov.rs/pages/article.php?id=11540

Ministarstvo finansija Republike Srbije. (2015). Tabela 3: Konsolidovani bilans države u periodu od 2005. do 2015. god. Preuzeto 20. oktobra 2015. sa http://www.mfin.gov.rs/pages/ article.php?\&id=7161\&change_lang=ls

OECD. (2010). Smernice OECD za primenu pravila o transfernim cenama za multinaconalna preduzeća i poreske uprave. Beograd: Srpsko fiskalno društvo.

Službeni glasnik RS. (2014). Zakon o porezu na dobit pravnih lica. Službeni glasnik RS, br. 25/2001,142/2014.

Službeni glasnik RS. (2015). Pravilnik o kamatnim stopama za koje se smatra da su u skladu sa principom „van dohvata ruke”. Službeni glasnik RS”, br. 17/2014, br. 23/2015.

Službeni glasnik RS. (2012). Pravilnik o listi jurisdikcija sa preferencijalnim poreskim sistemom. Službeni glasnik RS”, broj 122/2012.

Službeni glasnik RS. (2015). Pravilnik o sadržaju poreskog bilansa i drugim pitanjima od značaja za način utvrđivanja poreza na dobit pravnih lica. Službeni glasnik RS, br. 20/2014, 41/2015.

Službeni glasnik RS. (2014). Pravilnik o transfernim cenama i metodama koje se po principu "van dohvata ruke" primenjuju kod utvrđivanja cene transakcija među povezanim licima. Službeni glasnik RS, br. 61/2013, 8/2014.

United Nations. (2013). United Nations Practical Manual on Transfer Pricing for Developing Countries. New York: United Nations.

\section{CRITICAL REVIEW OF TRANSFER PRICING REGULATIONS IN SERBIA}

\section{Abstract:}

This paper presents a critical review of the most significant unfavorable normative solutions in the field of transfer pricing in the Republic of Serbia and provides recommendations on how to overcome them in future regulations. The paper also presents the positive effects of transfer pricing tax regulation reforms in 2013., with special emphasis on the effects of the new regulation on public revenues coming from corporate income tax.

\section{Key words:}

transfer pricing,

related parties,

“arm's length" principle,

corporate income tax, tax balance. 